\title{
Analysis of Wall Glucans from Yeast, Hyphal and Germ-tube Forming Cells of Candida albicans
}

\author{
By PRAMOD K. GOPAL,$^{1} \dagger$ MAXWELL G. SHEPHERD ${ }^{2}$ AND \\ PATRICK A. SULLIVAN ${ }^{1 *}$ \\ Department of Biochemistry ${ }^{1}$ and Experimental Oral Biology Unit, ${ }^{2}$ University of Otago, \\ PO Box 56, Dunedin, New Zealand
}

(Received 16 May 1984; revised 25 July 1984)

\begin{abstract}
Acid-soluble and alkali-insoluble glucan fractions were prepared from yeast, hyphal and germtube forming cells of Candida albicans. Alkali-insoluble glucan was also extracted from purified yeast cell walls. Paper chromatography of partial acid hydrolysates confirmed that the glucan preparations contained $\beta(1 \rightarrow 3)$ - and $\beta(1 \rightarrow 6)$-chains but no mixed intra-chain $\beta(1 \rightarrow 3) /(1 \rightarrow 6)$ linkages. Methylation and ${ }^{13} \mathrm{C}-\mathrm{NMR}$ analyses showed that the acid-soluble glucan consisted of a highly branched polymer composed mainly $(67.0 \%$ to $76.6 \%)$ of $\beta(1 \rightarrow 6)$-linked glucose residues. The alkali-insoluble glucan from yeast and hyphal cells contained from $29.6 \%$ to $38.9 \%$ $\beta(1 \rightarrow 3)$ and $43 \cdot 3 \%$ to $53 \cdot 2 \% \beta(1 \rightarrow 6)$ linkages. Alkali-insoluble glucan from germ-tube forming cells consisted of $67.0 \% \beta(1 \rightarrow 3)$ and $14 \% \beta(1 \rightarrow 6)$ linkages. Branch points accounted for $6.7 \%$, $12.3 \%$ and $17.4 \%$ of the residues in the alkali-insoluble glucan of yeast, germ-tube forming and hyphal cells, respectively.
\end{abstract}

\section{INTRODUCTION}

The cell wall of the dimorphic yeast Candida albicans is qualitatively similar in composition to that of Saccharomyces cerevisiae (for reviews see Cabib et al., 1982; Ballou, 1982; Duffus et al., 1982). Glucans, which include the main structural component, and mannoproteins constitute at least $80 \%$ of the $C$. albicans wall (Sullivan et al., 1983). Chitin, $0.6 \%$ of $C$. albicans yeast walls (Sullivan et al., 1983), is located mainly $(90 \%)$ in the bud scars but is also dispersed around the wall (Cabib et al., 1982; Tronchin et al., 1981).

Germ-tube forming cells, which constitute the initial stage in the yeast-mycelium transition, and hyphal cells contain three to five times more chitin than yeast cells (Braun \& Calderone, 1978; Sullivan et al., 1983; Chattaway et al., 1968). Cassone et al. (1973) and Scherwitz et al. (1978) have shown that the layered organization of the wall, visualized by electron microscopy, changes significantly with the onset of germ-tube formation; in particular an inner electrontranslucent layer becomes dominant in the germ-tube.

Previous studies suggest that the fine structure of the cell wall glucan changes with the age of the cells and the morphology. Gale et al. (1980) showed that the increased resistance to amphotericin exhibited by stationary-phase yeast cells was due to changes in the cell wall and that treatment with glucanases decreased the resistance. Chattaway et al. (1968) reported that although the alkali-insoluble glucan fractions from hyphal and yeast cells had similar glucose contents, treatment with a $\beta$-glucanase released $19 \%$ and $39 \%$ of the glucose, respectively.

Reports of detailed structural analysis of the $C$. albicans glucans are limited. Bishop et al. (1960) and Yu et al. (1967) extracted a glucan fraction from C. albicans serotypes A and B with boiling $3 \% \mathrm{NaOH}$. Non-reducing terminal and $\beta(1 \rightarrow 6)$-linked residues accounted for more than $70 \%$ of the glucose. These preparations contained only a trace (serotype A) and $17 \%$ (serotype B) of $\beta(1 \rightarrow 3)$-linked residues. However, the alkali-soluble fraction represents less than $10 \%$ of the

† Present address: Department of Biochemistry, University of California, Berkeley, Calif. 94720, USA. 
total glucan (Sullivan et al., 1983) and boiling $\mathrm{NaOH}$ may have caused some degradation of $\beta(1 \rightarrow 3)$ linkages by $\beta$-elimination. Gopal et al. (1984) analysed glucan nets from regenerating spheroplasts of $C$. albicans: the nets consisted of $43 \% \beta(1 \rightarrow 3)$-linked, $30 \% \beta(1 \rightarrow 6)$-linked and $9.5 \%$ branch point residues. This work gives some indication of the glucan structure in the intact walls, but glucan synthase activity may have been modified during the preparation of the spheroplasts (Duffus et al., 1982). In the present paper we describe the structural analysis of glucan fractions from yeast, hyphal and germ-tube forming cells of $C$. albicans.

\section{METHODS}

Organisms and culture conditions. Conditions for the maintenance of cultures, growth of yeast cells and germtube formation have been described previously (Shepherd \& Sullivan, 1976; Shepherd et al., 1980). C. albicans ATCC 10261 was used to produce yeast cells and germ-tube forming cells. Strain hOG301 was kindly provided by Dr R. T. M. Poulter, University of Otago, New Zealand. This mutant, isogenic with ATCC 10261, grows in a hyphal form at $28^{\circ} \mathrm{C}$ in yeast growth medium.

Isolation of cell wall glucans. Two methods were used to obtain wall glucans. In method I cell walls were prepared from a batch ( $298 \mathrm{~g}$ wet wt) of exponential-phase yeast cells (Sullivan et al., 1983). After lipid extraction the final yield of walls was $11.9 \mathrm{~g}$ dry wt. The cell wall preparation was extracted with $0.25 \mathrm{M}-\mathrm{Na}_{2} \mathrm{CO}_{3}(500 \mathrm{ml}$ per $\mathrm{g}$ dry wt) at $90{ }^{\circ} \mathrm{C}$ for $45 \mathrm{~min}$. The soluble extract of alkali-soluble glucan and mannoprotein (Stewart, 1975) was discarded and the insoluble fraction was washed extensively with distilled water. The insoluble residue was treated with pancreatin as described by Ram et al. (1981). Each incubation contained $20 \mathrm{ml} 0.05 \mathrm{M}-\mathrm{Tris} / \mathrm{HCl}$ buffer (pH 8.1), $40 \mu \mathrm{mol} \mathrm{CaCl}{ }_{2}, 20 \mathrm{mg}$ pancreatin and $400 \mathrm{mg}$ of the insoluble wall fraction. After incubation for $24 \mathrm{~h}$ at $37^{\circ} \mathrm{C}$, the insoluble residue was recovered by centrifuging, washed twice with distilled water and stored as a frozen pellet; the yield was $2.85 \mathrm{~g}$. In method II intact cells (yeast, hyphal or germ-tube forming cells) were sequentially extracted with alkali and acid as described by Manners et al. (1973a). In this procedure a known amount (10-15 g wet wt) of cells was extracted with 6 vols $3 \%(\mathrm{w} / \mathrm{v}) \mathrm{NaOH}$ at $70^{\circ} \mathrm{C}$ for $6 \mathrm{~h}$. The alkali-soluble extract was not analysed in this work. The cell residue was washed three times with water and the pooled extracts and washings were dialysed for $12 \mathrm{~h}$ against running tap water. The cell residue was extracted 15 times with $100 \mathrm{ml}$ volumes of $0.5 \mathrm{M}$-acetic acid at $100^{\circ} \mathrm{C}$, each for $4-6 \mathrm{~h}$. The combined extracts were dialysed, lyophilized and treated with $\alpha$-amylase. Each preparation, $150-200 \mathrm{mg}$, was suspended in $2.0 \mathrm{ml} \mathrm{0.1} \mathrm{M-sodium} \mathrm{phosphate} \mathrm{buffer}(\mathrm{pH} 6.9)$ containing $0.6 \mathrm{M}$ $\mathrm{NaCl}, 0.02 \%(\mathrm{w} / \mathrm{v}) \mathrm{NaN}_{3}$, chloramphenicol $\left(50 \mu \mathrm{g} \mathrm{ml}^{-1}\right)$ and $4 \mathrm{mg} \alpha$-amylase. After $12 \mathrm{~h}$ incubation at $30^{\circ} \mathrm{C}$, each acid-soluble preparation was dialysed against tap water for $12 \mathrm{~h}$ and freeze-dried. The insoluble residue remaining after the sequential acid extractions contained insoluble glucan. Each residue was washed with distilled water, treated with $\alpha$-amylase as described above, washed with water and stored as a pellet at $-20^{\circ} \mathrm{C}$. Neither the pancreatin used in method I (above) nor the $\alpha$-amylase used in method II exhibited $\beta$-glucanase activity towards laminarin and pustulan.

Analysis of glucan fractions. The methods used for methylation of glucan fractions, GLC of alditol acetate derivatives, partial acid hydrolysis of glucans and paper chromatography of the hydrolysates were as described previously (Gopal et al., 1984). Alditol acetate standards (Ram et al., 1981) were used to identify peaks in the GLC analyses. Partial acid hydrolysates of laminarin and pustulan were used as standards for paper chromatography (Gopal et al., 1984). Total carbohydrate was determined by the method of Dubois et al. (1956) using glucose as a standard.

${ }^{13} \mathrm{C}$-NMR spectroscopy. ${ }^{13} \mathrm{C}$-NMR spectra were recorded by Dr H. Wong, Chemistry Division, DSIR, Gracefield, New Zealand, with a Varian FT80A spectrometer operating at $20 \mathrm{MHz}$ in the pulsed mode [20 $\mu \mathrm{s}$ $(90 \%)$ pulse width, $0.82 \mathrm{~s}$ repetition time]. The solvent deuterium oxide signal was used as a field frequency lock signal and chemical shifts were expressed in p.p.m. downfield from external trimethyl silane. All spectra were recorded at $90^{\circ} \mathrm{C}$ and a spectral width of $5 \mathrm{kHz}$.

Materials. $\alpha$-Amylase (from human saliva) and pancreatin were from Sigma. Laminarin was purchased from the US Biochemical Corp., Cleveland, Oh., USA, and pustulan was obtained from Calbiochem.

\section{RESULTS}

\section{Isolation of cell wall glucan}

Method I, used to obtain glucan from purified yeast cell walls, involved mild alkaline treatment followed by incubation with pancreatin to remove residual glycogen. The final yield of $2.58 \mathrm{~g}$ was $24 \%$ of the original wall preparation and was comparable with the amount of insoluble 
glucan obtained in a previous study of the C. albicans wall (Sullivan et al., 1984). This glucan preparation was obtained by mild procedures so that the subsequent structural analyses would reflect the relative abundance of $\beta(1 \rightarrow 3)$ and $\beta(1 \rightarrow 6)$ linkages in the cell wall. Method II used intact cells as the starting material and yielded three glucan fractions: an alkali-soluble fraction which was not analysed in this work, an acid-soluble fraction and insoluble glucan. These fractions were prepared from the three morphological forms of $C$. albicans. The crude fractions were contaminated with glycogen $(12-14 \%$ of the insoluble fractions and $35-44 \%$ of the crude acid-soluble fractions). After treatment with amylase the carbohydrate present in the insoluble and acid-soluble fractions, respectively was (mg): yeast, 375 and 136; hyphal, 150 and 60; and germ-tube cells, 255 and 94 . These data should not be interpreted as quantitative yields since the objective in this extraction procedure was purity rather than recovery. It should be noted, however, that the relative yields of insoluble glucan and acid-soluble glucan were approximately $2 \cdot 7: 1$ for each type of cell.

\section{Partial acid hydrolysis}

Paper chromatography of partial acid hydrolysates of insoluble glucan and acid-soluble glucan prepared by method II revealed glucose, laminaribiose and oligomers of this series up to laminaritetrose, gentiobiose and oligomers up to gentiotetrose. The hydrolysates did not contain any unidentified sugars. These results suggested that the glucan fractions were substantially free of other glucans and that the glucan chains did not contain mixed intrachain $\beta(1 \rightarrow 3)$ and $\beta(1 \rightarrow 6)$ linkages.

\section{Methylation analysis}

The acid-soluble glucan fraction from germ-tube forming cells was not analysed further. The other glucan fractions were subjected to three cycles of methylation. The absence of infra-red absorption in the region $3200-3600 \mathrm{~cm}^{-1}$ indicated that essentially all the available hydroxyl groups had been methylated. Hydrolysates of these preparations contained the four $O$-methyl glucitol acetate derivatives expected from branched $(1 \rightarrow 3)-/(1 \rightarrow 6)-\beta$-glucans. A small amount $(2-$ $3 \%$ ) of 4,6-di-O-methyl glucitol acetate was also detected in some hydrolysates. This arises because of undermethylation or demethylation and the peak was not included in the calculations of percentage composition.

The insoluble glucan fraction from purified yeast cell walls contained near equimolar amounts of $\beta(1 \rightarrow 3)$ - and $\beta(1 \rightarrow 6)$-linked glucose (Table 1$)$. This glucan fraction is highly branched since $10 \%$ and $7.6 \%$ of the glucose residues were non-reducing end groups and branch points, respectively.

\section{Table 1. Methylation analysis of the insoluble glucan fraction from yeast cell walls}

The insoluble glucan fraction was extracted from purified yeast cell walls by method I, methylated, hydrolysed and acetylated (see Methods). The peaks were identified from GLC retention times and also by adding authentic samples as internal standards. The percentage composition was determined by making three copies of the GLC traces, cutting and weighing each peak. Individual percentages were calculated from the individual and total weights; molar ratios were calculated from the percentage composition data.

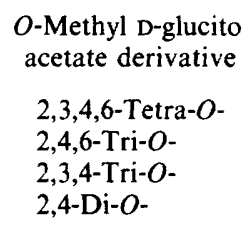

$O$-Methyl D-glucitol

2,3,4,6-Tetra- $O$ -

2,3,4-Tri-O-

2,4-Di-O
Type of linkage

Non-reducing end group

$(1 \rightarrow 3)$

$(1 \rightarrow 6)$

Branch point C-1, C-3, C-6

$\begin{array}{cl}\begin{array}{c}\text { Percentage } \\ \text { composition }\end{array} & \begin{array}{c}\text { Molar } \\ \text { ratio }\end{array} \\ 10.0 & 1.0 \\ 38.9 & 4.7 \\ 43.3 & 5.3 \\ 7.6 & 0.86\end{array}$


Table 2. Methylation analysis of glucan fractions from yeast, hyphal and germ-tube forming cells

The glucan fractions were extracted from intact cells by method II, methylated, hydrolysed and acetylated (see Methods). The analyses were done as summarized in Table 1.

\begin{tabular}{|c|c|c|c|}
\hline $\begin{array}{l}O \text {-Methyl D-glucitol } \\
\text { acetate derivative }\end{array}$ & Type of linkage & $\begin{array}{l}\text { Percentage } \\
\text { composition }\end{array}$ & $\begin{array}{l}\text { Molar } \\
\text { ratio }\end{array}$ \\
\hline $\begin{array}{l}\text { Yeast insoluble } \\
\text { 2,3,4,6-Tetra- } O \text { - } \\
\text { 2,4,6-Tri-O- } \\
\text { 2,3,4-Tri-O- } \\
\text { 2,4-Di- } O-\end{array}$ & $\begin{array}{l}\text { Non-reducing end group } \\
(1 \rightarrow 3) \\
(1 \rightarrow 6) \\
\text { Branch point C-1, C-3, C-6 }\end{array}$ & $\begin{array}{r}8 \cdot 1 \\
31 \cdot 8 \\
53 \cdot 2 \\
6 \cdot 7\end{array}$ & $\begin{array}{l}1 \cdot 0 \\
3 \cdot 6 \\
6 \cdot 1 \\
0 \cdot 7\end{array}$ \\
\hline $\begin{array}{l}\text { Yeast acid-soluble } \\
\text { 2,3,4,6-Tetra- } O- \\
\text { 2,4,6-Tri-O- } \\
\text { 2,3,4-Tri-O- } \\
\text { 2,4-Di- } O-\end{array}$ & $\begin{array}{l}\text { Non-reducing end group } \\
(1 \rightarrow 3) \\
(1 \rightarrow 6) \\
\text { Branch point C-1, C-3, C-6 }\end{array}$ & $\begin{array}{r}6 \cdot 3 \\
11 \cdot 7 \\
76 \cdot 6 \\
5 \cdot 3\end{array}$ & $\begin{array}{r}1.0 \\
1.4 \\
11 \cdot 8 \\
0.8\end{array}$ \\
\hline $\begin{array}{l}\text { Hyphal insoluble } \\
2,3,4,6-\text { - } \text {-tra- } O- \\
2,4,6-\text { Tri- } O- \\
2,3,4-\text { Tri- } O- \\
\text { 2,4-Di-O- }\end{array}$ & $\begin{array}{l}\text { Non-reducing end group } \\
(1 \rightarrow 3) \\
(1 \rightarrow 6) \\
\text { Branch point C-1, C-3, C-6 }\end{array}$ & $\begin{array}{r}5 \cdot 8 \\
29 \cdot 6 \\
47 \cdot 1 \\
17 \cdot 4\end{array}$ & $\begin{array}{l}1 \cdot 0 \\
4 \cdot 9 \\
7 \cdot 2 \\
2 \cdot 4\end{array}$ \\
\hline $\begin{array}{l}\text { Hyphal acid-soluble } \\
\text { 2,3,4,6-Tetra- } O \text { - } \\
\text { 2,4,6-Tri-O- } \\
\text { 2,3,4-Tri-O- } \\
\text { 2,4-Di- } O \text { - }\end{array}$ & $\begin{array}{l}\text { Non-reducing end group } \\
(1 \rightarrow 3) \\
(1 \rightarrow 6) \\
\text { Branch point C-1, C-3, C-6 }\end{array}$ & $\begin{array}{r}10 \cdot 1 \\
14 \cdot 3 \\
67 \cdot 0 \\
8 \cdot 4\end{array}$ & $\begin{array}{l}1 \cdot 0 \\
1 \cdot 3 \\
7 \cdot 0 \\
0 \cdot 8\end{array}$ \\
\hline $\begin{array}{l}\text { Germ-tube cells insolubl } \\
\text { 2,3,4,6-Tetra- } O \text { - } \\
\text { 2,4,6-Tri-O- } \\
\text { 2,3,4-Tri-O- } \\
\text { 2,4-Di-O- }\end{array}$ & $\begin{array}{l}\text { Non-reducing end group } \\
(1 \rightarrow 3) \\
(1 \rightarrow 6) \\
\text { Branch point C-1, C-3, C-6 }\end{array}$ & $\begin{array}{r}5 \cdot 8 \\
67 \cdot 0 \\
14 \cdot 0 \\
12 \cdot 3\end{array}$ & $\begin{array}{r}1 \cdot 0 \\
10 \cdot 8 \\
2 \cdot 3 \\
1 \cdot 9\end{array}$ \\
\hline
\end{tabular}

Table 2 summarizes the methylation analyses of the glucan fractions extracted from intact cells. The acid-soluble glucan fractions consisted predominantly $(67-76 \%)$ of $\beta(1 \rightarrow 6)$-linked glucose residues with smaller amounts $(11 \cdot 7-14 \cdot 3 \%)$ of $\beta(1 \rightarrow 3)$ linkages. As expected $2,3,4,6-$ tetra- $O$-methyl glucitol acetate (non-reducing end groups) and 2,4-di- $O$-methyl glucitol acetate (branch points) were present in near equivalent amounts. The relative abundance of branch point residues $(5 \cdot 3-8 \cdot 4 \%)$ indicates that acid-soluble glucans are highly branched.

The insoluble glucan fractions from intact yeast and hyphal cells were quite similar with respect to their percentage $\beta(1 \rightarrow 3)(31 \cdot 8 \%$ and $29 \cdot 6 \%)$ and $\beta(1 \rightarrow 6)$ linkages $(53.2 \%$ and $47 \cdot 1 \%)$. Both glucan preparations were highly branched as judged from the percentage of non-reducing end groups but surprisingly there was a threefold excess of di- $O$-methyl glucitol acetate over tetra-O-methyl glucitol acetate in the hyphal preparation. A similar result $(5 \cdot 8 \%$ tetra- $O$-methyl glucitol acetate and $12.3 \% \mathrm{di}-O$-methyl glucitol acetate) was obtained with the insoluble fraction from germ-tube forming cells. The latter cells yielded an insoluble glucan with a different composition. In this preparation $\beta(1 \rightarrow 6)$-linked glucans only accounted for $14 \%$ of the residues while $67 \%$ of the glucose units were $\beta(1 \rightarrow 3)$-linked.

\section{${ }^{13} C-N M R$ spectroscopy}

Laminarin and pustulan used as standard glucans showed six chemical shifts consistent with previously published data (Colson et al., 1974; Saito et al., 1977; Bassieux et al., 1977). The acidsoluble fractions (yeast, germ-tube and hyphal) gave the same well-resolved spectrum and the spectra of laminarin and yeast acid-soluble glucan are shown in Fig. 1. The 105.0 p.p.m. signal is indicative of a $\beta$-anomeric carbon. No signal was detected in the 100-103 p.p.m. region thus confirming the absence of $\alpha$-glycosidic contaminants. Furthermore, while laminarin showed a clear $O$-substituted C-3 signal at 87.0 p.p.m., no such signal was present in the spectra of the acid-soluble glucan or pustulan. The chemical shifts (p.p.m.) of the acid-soluble glucan as shown in Fig. 1 are assigned as follows: C-1 (105.0), C-2 (75.3), C-3 (78.0), C-4 (72.1), C-5 (77.1), and $O$ - 


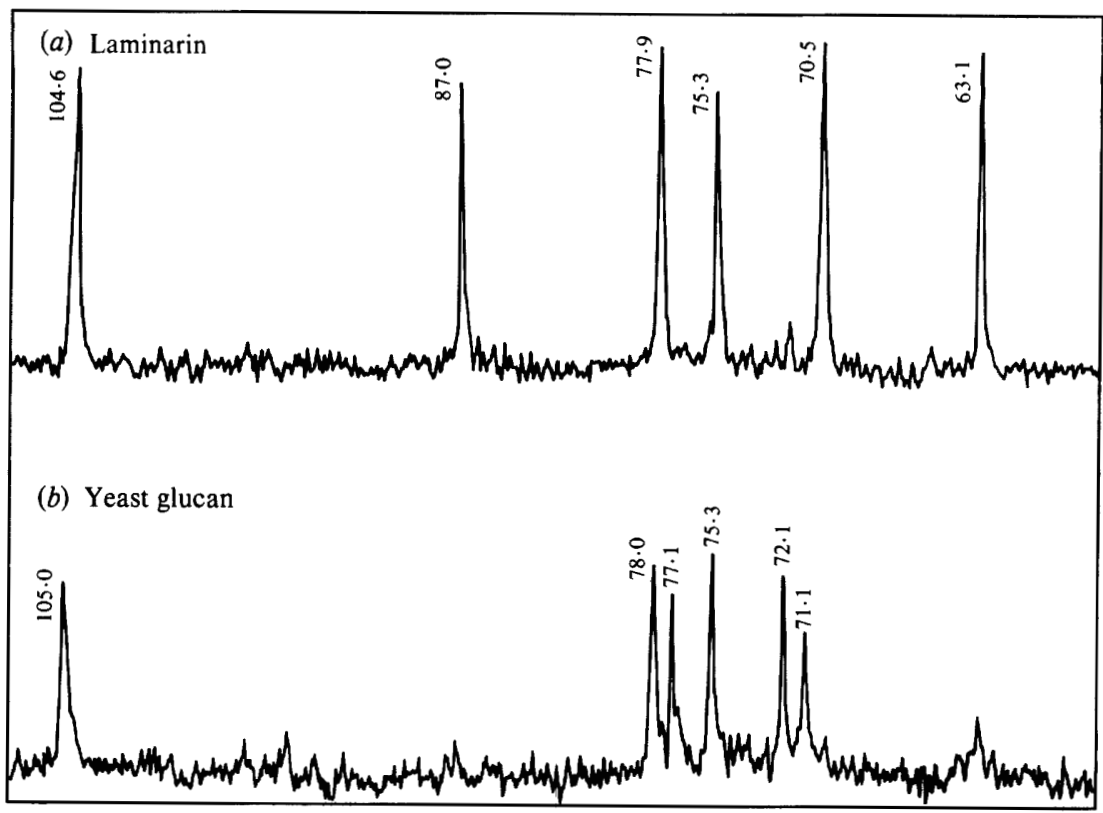

Fig. $1 .{ }^{13} \mathrm{C}-\mathrm{NMR}$ spectrum of acid-soluble glucan. The spectra of $(a)$ laminarin $\left(100 \mathrm{mg} \mathrm{ml}^{-1}\right)$ and $(b)$ yeast acid-soluble glucan $\left(85 \mathrm{mg} \mathrm{ml} \mathrm{m}^{-1}\right)$ were recorded in $\mathrm{D}_{2} \mathrm{O}$ as described in Methods. The spectra were obtained after 61000 and 51000 accumulations, respectively. Values for the chemical shifts are given as p.p.m. The spectrum of pustulan $\left(100 \mathrm{mg} \mathrm{ml}^{-1}\right)$ showed chemical shifts at 104.9, 77.9, $77 \cdot 0,75 \cdot 2,71.9$ and 71.0 p.p.m. (not shown).

substituted C-6 (71-1). These data are essentially the same as those reported for the $(1 \rightarrow 6)-\beta$ glucan from Gyrophora esculenta (Saito et al., 1977) and pustulan from Umbilicaria pustulata (Bassieux et al., 1977). In particular, the acid-soluble glucan and (1-6)- $\beta$-glucans, but not laminarin, have a chemical shift at 70.0 p.p.m. which has been assigned to the $O$-substituted C-6 (Saito et al., 1977).

\section{DISCUSSION}

The present work has established that the alkali-insoluble glucan extracted either from intact cells or from purified cell walls of $C$. albicans contains from $31.8 \%$ (yeast cells) to $67.0 \%$ (germtube forming cells) of $\beta(1 \rightarrow 3)$-linked residues. It is generally accepted (Duffus et al., 1982; Cabib et al., 1982) that $(1 \rightarrow 3)$ - $\beta$-glucan in the alkali-insoluble fraction of Saccharomyces cerevisiae provides the rigid framework of the cell wall. This type of glucan probably fulfils the same role in $C$. albicans. Consistent with this proposal, it has previously been shown that Zymolyase, a cell wall lytic preparation which contains $(1 \rightarrow 3)-\beta$ - but not $(1 \rightarrow 6)-\beta$-glucanase activity readily converts intact yeast cells of $C$. albicans to spheroplasts (Poulter et al., 1981; Gopal et al., 1984). Zymolyase is less effective with the mycelial mutant hOG301 and germ-tube forming cells ( $R$. Surarit, M. J. Hubbard, M. G. Shepherd \& P. A. Sullivan, unpublished results) and this may reflect the differing amounts of branching in these cell walls.

From the paper chromatography of partial acid hydrolysates it was concluded that $C$. albicans glucan contains chains of either $\beta(1 \rightarrow 3)$ - or $\beta(1 \rightarrow 6)$-linked glucose but no mixed intra-chain $\beta(1 \rightarrow 3) / \beta(1 \rightarrow 6)$ linkages. Further studies would be needed to determine the type of linkages present in the backbone and the side chains. It is clear, however, that insoluble glucan from $C$. albicans and $S$. cerevisiae differs in structural detail. The former is highly branched $(6.7 \%, 12 \cdot 3 \%$ and $17.4 \%$ branch point residues in yeast, germ-tube forming and hyphal cells) and contains from $14 \%$ to $52 \cdot 2 \%$ of $\beta(1 \rightarrow 6)$-linked residues. In contrast, the insoluble glucan from $S$. cerevisiae contains $3 \%$ of branch point and $\beta(1 \rightarrow 6)$-linked residues (Manners et al., 1973a,b). Bacon (1979) 
has suggested that the extent of branching in $S$. cerevisiae insoluble glucan could result in insufficient unsubstituted $\beta(1 \rightarrow 3)$ sequences for a triple helix conformation (Rees, 1973) in yeast glucan microfibrils. A triple helix conformation would be even less likely on these grounds with $C$. albicans glucan. Ballou (1982) has suggested that $(1 \rightarrow 3)-\beta$-glucan in yeast walls may have a double helix structure involving extensive hydrophobic interactions.

The morphology of $C$. albicans is not determined simply by the ratio of $\beta(1 \rightarrow 3)$ to $\beta(1 \rightarrow 6)$ linkages, as this value was similar in the insoluble glucan from yeast and hyphal cells. However, insoluble glucan from hyphal and germ-tube forming cells contains more branch point residues $(17.4 \%$ and $12.3 \%$, respectively) and so this may be a feature of apical wall extension. These values, however, were somewhat surprising. In methylation analyses the amounts of $\mathrm{di}-O$ methyl glucitol acetate (branch points) and tetra- $O$-methyl glucitol acetate (non-reducing end groups) are usually equivalent. The molar ratios for branch point residues in insoluble and acidsoluble glucans from yeast varied from 0.70 to 0.86 (Tables 1 and 2). The values for insoluble glucan from germ-tube and hyphal cells were 1.9 and $2 \cdot 4$, respectively. A possible explanation for these data is that the insoluble glucan in germ-tube and hyphal cells is, in part, covalently linked to another wall polymer via non-reducing end groups. Sietsma \& Wessels (1981) have reported that the R-glucan in yeasts and fungi is linked in varying amounts to chitin. It is interesting to note that hyphal and germ-tube cells contain three to five times more chitin than do yeast cells (Chattaway et al., 1968; Sullivan et al., 1983).

Perhaps the most striking result from the present work was the increased amount $(67 \%)$ of $\beta(1 \rightarrow 3)$-linked glucose in the insoluble glucan from germ-tube forming cells, compared with $31.8 \%$ in yeast cells. This glucan preparation was obtained from intact cells and, taking into account the $(1 \rightarrow 3)-/(1 \rightarrow 6)-\beta$-glucan in the mother cell, it seems likely that the glucan in the germtube consists mainly, if not entirely, of $\beta(1 \rightarrow 3)$-linked glucan. Exclusive synthesis of $(1 \rightarrow 3)-\beta$ glucan may occur during the morphogenic transition and if so this would be somewhat analogous to regenerating spheroplasts, which preferentially synthesize $\beta(1 \rightarrow 3)$-linked glucan (Kreger \& Kopeká, 1975; Gopal et al., 1984). Changes in the relative amounts of $(1 \rightarrow 3)$ - and $(1 \rightarrow 6)-\beta$-glucan may contribute to the altered wall layering (Cassone et al., 1973) and increased cell wall porosity (Sullivan et al., 1984) noted during germ-tube formation.

It has been shown during the present study that an acid-soluble $(1 \rightarrow 6)$ - $\beta$-glucan fraction can be extracted from C. albicans. Acid-soluble glucan constitutes less than $15 \%$ of the $S$. cerevisiae wall, contains $65 \% \beta(1 \rightarrow 6), 19 \% \beta(1 \rightarrow 3)$ and $16 \%$ branch point residues (Manners et al., $1973 \mathrm{~b}$ ). Yeast and hyphal acid-soluble glucans from $C$. albicans contain fewer branch points $(5 \cdot 3 \%$ and $8.4 \%)$ and $\beta(1 \rightarrow 3)$ linkages $(11.7 \%$ and $14.3 \%)$, respectively. NMR analysis clearly confirmed the presence of $\beta(1 \rightarrow 6)$ linkages. The complete absence of a ${ }^{13} \mathrm{C}$-signal for $\beta(1 \rightarrow 3)$ linkages in the acid-soluble glucan suggests that these residues were in an immobilized or ordered state. Saito $e t$ al. (1977) have reported a similar situation for a 16200 molecular weight fraction derived from lentinan. This polymer consisted of a branched $(1 \rightarrow 3)-\beta$-glucan with $\beta(1 \rightarrow 3)$ and $\beta(1 \rightarrow 6)$ side chains but it did not exhibit a ${ }^{13} \mathrm{C}$-signal for $\beta(1 \rightarrow 3)$ linkages. The acid-soluble glucan from $C$. albicans may therefore consist of an ordered state $\beta(1 \rightarrow 3)$ backbone with $\beta(1 \rightarrow 6)$ side chains.

This project was supported by grants from the Medical Research Council of New Zealand and the University of Otago.

\section{REFERENCES}

Bacon, J. S. D. (1979). Nature and disposition of polysaccharides within the cell envelope. In Yeast Cell Envelopes: Biochemistry, Biophysics and Ultrastructure, vol. I, pp. 66-84. Edited by W. N. Arnold. Florida, USA: CRC Press.

BALlou, C. E. (1982). Yeast cell wall and cell surface. In Molecular Biology of the Yeast Saccharomyces: Metabolism and Gene Expression, pp. 335-360. Edited by J. N. Strathern, E. W. Jones \& J. R. Broach. Cold Spring Harbor: Cold Spring Harbor Laboratory.

BassieuX, D., Gagnaire, D. \& Vignon, M. (1967).
Etude par R.M.N.- ${ }^{-3} \mathrm{C}$ et ${ }^{1} \mathrm{H}$ du $(1 \rightarrow 6)$ - $\beta$-D-glucane et des oligosaccharides linéaires et cycliques correspondants. Carbohydrate Research 56, 19-33.

Bishop, C. T., Blank, F. \& Gardner, P. E. (1960). The cell wall polysaccharides of Candida albicans: glucan, mannan and chitin. Canadian Journal of Chemistry 38, 869-881.

Braun, P. C. \& Calderone, R. A. (1978). Chitin synthesis in Candida albicans: comparison of yeast and hyphal forms. Journal of Bacteriology 133, 14721477.

CABIB, E., Roberts, R. \& Bowers, B. (1982). Synthesis 
of the yeast cell wall and its regulation. Annual Review of Biochemistry 51, 763-793.

Cassone, A., Simonetti, N. \& Strippoli, V. (1973). Ultrastructural changes in the wall during germ-tube formation from blastospores in Candida albicans. Journal of General Microbiology 77, 417-426.

Chattaway, F. W., Holmes, M. R. \& Barlow, A. J. E. (1968). Cell wall composition of the mycelial and blastospore forms of Candida albicans. Journal of General Microbiology 51, 367-376.

Colson, P., Jennings, H. J. \& Smith, I. C. (1974). Composition, sequence and conformation of polymers and oligomers of glucose as revealed by Carbon-13 Nuclear Magnetic Resonance. Journal of the American Chemical Society 96: 26, 80818087.

Dubois, M., Gilles, K. A., Hamilton, J. K., Rebers, P. A. \& SMITH, F. (1956). Colorimetric method for determination of sugars and related substances. Analytical Chemistry 28, 350-356.

Duffus, J. H., Levi, C. \& Manners, D. J. (1982). Yeast cell wall glucans. Advances in Microbial Physiology 23, 151-181.

Gale, E. F., Ingram, J., Kerridge, D., Notario, V. \& WAYMAN, F. (1980). Reduction of amphotericin resistance in stationary phase cultures of Candida albicans by treatment with enzymes. Journal of General Microbiology 117, 383-391.

Gopal, P. K., Sullivan, P. A. \& Shepherd, M. G. (1984). Isolation and structure of glucan from regenerating spheroplasts of Candida albicans. Journal of General Microbiology 130, 1217-1225.

KREGer, D. R. \& KopeckÁ, M. (1975). On the nature and formation of the fibrillar nets produced by protoplasts of Saccharomyces cerevisiae in liquid media : an electronmicroscopic, X-ray diffraction and chemical study. Journal of General Microbiology 92 , 207-220.

Manners, D. J., Masson, A. J. \& Patterson, J. C. $(1973 a)$. The structure of $\beta(1 \rightarrow 3)$-D-glucan from yeast cell walls. Biochemical Journal 135, 19-30.

Manners, D. J., Masson, A. J., Patterson, J. C., BJorndal, H. \& LindBerG, B. $(1973 b)$. The structure of a $\beta(1 \rightarrow 6)$-D-glucan from yeast cell walls. Biochemical Journal 135, 31-36.

Poulter, R., JefFery, K., Hubbard, M. J., Sullivan, P. A. \& SHePHeRD, M. G. (1981). Parasexual genetic analysis of Candida albicans by spheroplast fusion. Journal of Bacteriology 146, 833-840.

RAM, S., Beyer, R., Shepherd, M. G. \& Sullivan, P. A. (1981). Isolation and analysis of neutral glucans from Ecklonia radiata and Cystophora scalaris. Carbohydrate Research 96, 95-104.

REES, D. A. (1973). Polysaccharide conformation. In Carbohydrates, MTP International Review of Science: Organic Chemistry, series I, vol. 7, pp. 251-283. Edited by G. O. Aspinall. London: Butterworths.

SaIto, H., OHKI, T., Takasuka, N. \& Sasaki, T. (1977). A ${ }^{13}$ C-NMR spectral study of a gel forming branched ( $1 \rightarrow 3$ )- $\beta$-D-glucan, (lentinan) from Lentinus edodes and its acid-degraded fractions. Structure and dependence of conformation on molecular weight. Carbohydrate Research 58, 293-305.

Scherwitz, C., Martin, R. \& UeberberG, H. (1978). Ultrastructural investigations of the formation of Candida albicans germ-tubes and septa. Sabouraudia 16, 115-124.

ShePherd, M. G. \& Sullivan, P. A. (1976). The production and growth characteristics of yeast and mycelial forms of Candida albicans in continuous culture. Journal of General Microbiology 93, 361-370.

SHEPHERD, M. G., ChIEW, Y. Y., RAM, S. P. \& Sullivan, P. A. (1980). Germ-tube induction in Candida albicans. Canadian Journal of Microbiolog. 26, 21-26.

SiETSMa, J. H. \& Wessels, J. G. H. (1981). Solubility of $(1 \rightarrow 3)-\beta-D /(1 \rightarrow 6)-\beta$-D-glucan in fungal walls: importance of presumed linkage between glucan and chitin. Journal of General Microbiology 125, 209-212.

StewaRT, P. R. (1975). Analytical methods for yeasts. Methods in Cell Biology 12, 111-147.

Sullivan, P. A., Chiew, Y. Y., Molloy, C., TempleTON, M. D. \& SHEPHERD, M. G. (1983). An analysis of the metabolism and cell wall composition of Candida albicans during germ-tube formation. Canadian Journal of Biochemistry 29, 1514-1525.

Sullivan, P. A., Mchugh, N. J., Romana, L. K. \& SHEPHERD, M. G. (1984). The secretion of $N$ acetylglucosaminidase during germ-tube formation in Candida albicans. Journal of General Microbiology' 130, 2213-2218.

Tronchin, G., Poulain, D., Herbaut, J. \& Biguet, J. (1981). Localization of chitin in the cell wall of Candida albicans by means of wheat germ agglutinin. Fluorescence and ultrastructural studies. European Journal of Cell Biology 26, 121-128.

Yu, R. J., Bishop, C. T., COOPER, F. P., HASENCleVER, H. F. \& BlanK, F. (1967). Structural studies of mannans from Candida albicans (serotypes A \& B), Candida parapsilosis, Candida stellatoidea \& Candida tropicalis. Canadian Journal of Chemistry 45, 22072211. 